\title{
Saraus das periferias de São Paulo: poesia entre tragos, silêncios e aplausos ${ }^{1}$
}

Lucía Tennina ${ }^{2}$

A palavra sarau não é recente. Diversas músicas, romances, cartas, crônicas e memórias do século XIX, da Europa e da América, fazem referência a essas luxuosas reuniões de amigos, artistas, políticos e livreiros, que, com frequência variada, encontravam-se em casas de certas figuras da alta sociedade ou em espaços exclusivos desses setores - como clubes e livrarias - para tornar suas criações públicas. Registros desses encontros podem ser encontrados, por exemplo, nas crônicas de Machado de Assis, em que há um grande sarau de jovens na casa do senador Nabuco ou no clube Beethoven, que "reunia entre seus sócios o que de melhor na sociedade fluminense havia" (Ilustração Brasileira, 1877 apud Pinho, 2004, p. 238).

O termo sarau deriva etimologicamente do latim serum, que significa "tarde", período em que justamente se davam os encontros. A dança, a música e a literatura eram as artes protagonistas das reuniões, apesar de a atenção dos presentes concentrar-se também na comida que era servida, na vestimenta dos convidados e nos modos de recepção (Pinho, 2004, p. 238). As representações, nesse sentido, eram duplas. Havia um interesse artístico, que corria paralelo à intenção de oferecer capitais simbólicos necessários a fim de legitimar as obras frente aos representantes da sociedade aristocrática e da intelectualidade da época. Ao mesmo tempo, havia um interesse em exibir a posição de classe.

Alguns saraus angariavam mais prestígio que outros, consideração vinculada à qualidade e ao papel social dos assistentes. No princípio do século XX, um dos mais importantes espaços em que se realizavam saraus em São Paulo era o salão da Villa Kirial:

O salão da Villa Kyrial, que, provavelmente, foi o berço do 'nascimento' da Semana de 22, era um dos mais importantes da época para os artistas paulistas. A chácara do gaúcho José de Freitas Valle, que foi para São Paulo para estudar Direito, era, na década de 1910, ponto de muitos artistas, e também o local onde se organizavam saraus literários, audições musicais, banquetes e ciclos de conferências dos quais participavam Lasar Segall, Guilherme de Almeida,

\footnotetext{
${ }^{1}$ Tradução de Paulo Thomaz.

${ }^{2}$ Doutoranda em letras e professora de literatura brasileira e portuguesa na Faculdade de Filosofia e Letras, Universidade de Buenos Aires, Buenos Aires, Argentina. Pesquisadora Associada ao Programa Avançado em Cultura Contemporânea da UFRJ. E-mail: luciatennina@gmail.com
} 
Blaise Cendrars, Oswald de Andrade e Mário de Andrade, dentre outros (Silva, 2004, p. 24).

Os saraus constituíam um microcosmo social que evidenciava uma sociedade em formação, caracterizada pelo reposicionamento dos indivíduos que vivenciavam a passagem de um passado agrícola e patriarcal para um mundo urbano de ofícios diferenciados, sustentado por novas alianças e disputas de poder (Sorá, 2010, p. 66).

No começo do século XXI, essa prática, no momento já deslocada pela cultura letrada, é retomada e ressignificada manifestadamente nas regiões periféricas da cidade de São Paulo. Porém, como todo deslocamento de um domínio de origem para outro, não se tratava de uma cópia dos saraus das salas das elegantes casas das elites paulistas, mas de múltiplos processos que os tornaram diferentes a ponto de não permitir comparações entre si. Trata-se, pode-se dizer, de uma apropriação livre que mantém apenas o rótulo sarau e a arte como palavra de ordem central.

Os saraus das periferias podem ser definidos, de um modo breve, como reuniões em bares de diferentes bairros suburbanos da cidade de São Paulo, onde os moradores declamam ou leem textos próprios ou de outros diante de um microfone, durante aproximadamente duas horas. Muitos bares - espaços nos quais normalmente acontecem os episódios que se transformam em estatísticas posteriormente (os assassinatos e o alcoolismo) - funcionam, desde então, também como centros culturais. Diz Sérgio Vaz (em entrevista à autora):

O espaço que o Estado deixou para nós é o bar, aqui não tem museu, não tem teatro, não tem cinema, não tem lugar para se reunir, e o bar é o nosso centro cultural, onde as pessoas se reúnem para discutir os problemas do bairro, aonde as pessoas vêm se reunir depois do trabalho, onde as pessoas se reúnem quando vai jogar bola, ou quando é um aniversário, se reúnem para ouvir e tocar samba, então o bar é a nossa ágora, a nossa assembleia, o nosso teatro, tudo, a única coisa que o Estado deixou para nós foi o bar, então a gente ocupou o bar. É só isso o que a gente tem, então, é isso o que vamos transformar.

Sérgio Vaz é o organizador do primeiro espaço batizado como sarau (Sarau da Cooperifa), encarregado de estabelecer, além do nome, uma série de fórmulas e o modus operandi que se tornaram regras incorporadas por todos os frequentadores deste e dos posteriores saraus que foram sendo formados. 
Efetivamente, a partir de 2001, cada vez mais saraus ${ }^{3}$ têm sido organizados nas regiões suburbanas da cidade de São Paulo. Anualmente, o número tem se multiplicado, preenchendo o calendário e salpicando o mapa. Os saraus da periferia conformam um circuito atravessado por uma rede de frequentadores, que transitam de um bairro a outro sem levar em consideração as grandes distâncias geográficas, nem as distâncias que impõem a realidade do tráfico e da pobreza. Partindo da ideia de que um espaço não se define a partir de pontos cardeais, mas que está determinado, caracterizado e distinguido a partir de uma dinâmica social, pode-se compreender nos saraus a disposição do espaço "periferia" em termos distintos ao que expressa o sentido comum. Nas palavras de Durkheim:

El espacio mismo [...] no tiene ni derecha ni izquierda, ni arriba ni abajo, ni norte ni sur, etc. todas estas distinciones provienen de que se ha atribuido a las regiones valores afectivos diferentes. Y como todos los hombres de una misma civilización se representan el espacio de la misma manera, es necesario evidentemente que esos valores afectivos y las distinciones que dependen de ellos les sean igualmente comunes; lo que implica casi necesariamente que ellas son de origen social (Durkheim, 1965, p. 16).

Portanto, pode-se afirmar que é possível pensar a periferia já não como um espaço delimitado a partir de valores econômicos e socioestruturantes, mas como um mapa afetivo traçado a partir do circuito de saraus e seus frequentadores. Nesse sentido, os estigmatizados bairros do Capão Redondo, Campo Limpo e Brasilândia, por exemplo, passam a ser chamados de "o bairro do Sarau da Vila Fundão", "o do Sarau do Binho", "o do Sarau Poesia na Brasa".

Além da ressignificação do espaço "periferia" que o mapa dos saraus produz, uma ideia de "periferia" como modo de vida acompanha as noites de sarau. Quase todos os poemas declamados têm a ver com a conformação de uma geografia afetiva a partir de uma atenção voltada para as vivências apreendidas no dia a dia da comunidade, traçando uma estética particular nessas reconfigurações. Um claro exemplo, nesse sentido, é este fragmento do poema de Serginho Poeta, "Faltei ao serviço":

\footnotetext{
3 Antes desta data havia reuniões impulsionadas pela literatura. A que mais se aproxima ao que hoje são os saraus foi "Noites da Vela", iniciada na metade da década de 1990, organizada por Binho em seu antigo bar. Binho diz a respeito (em entrevista a autora): "Em 95, em 96, a gente realizava no bar um evento que se chamava 'Noite da vela', não nesse bar aqui, um anterior a esse. Na ' Noite da Vela' que a gente colocava o lado $\mathrm{B}$ dos discos, aquele que não toca em rádio, não toca em nada, e eram os bolachões, vinil, e a gente colocava para ouvir, né? Aí no meio dessa atmosfera, sempre alguém falava, 'ah, deixe falar uma poesia?' e entre uma música e outra falava uma poesia".
} 
Meu patrão que me desculpe

Mas hoje vai ficar me esperando

No mesmo horário de sempre

O relógio tocou como um louco

Desliguei e resolvi dormir mais um pouco

Foi aí que me atrasei

E como me atrasei!!!

Levantei com a cara toda amassada

Parecia que eu tinha levado uma porrada

O espelho ainda me disse:

-Bem feito!

Quem mandou se encantar com a batucada?

E olha que espelho não mente

Daqui a pouco

Não preciso nem de pente

E o que sobrou do meu cabelo

'Tá ficando tudo grisalho

Deve ser porque minha vida

É só trabalho, trabalho, trabalho...

Nesses tantos anos

Trabalhei pra caramba,

Será que não tenho o direito de passar uma noite no samba?

Dizem, por aí

Que a boemia atrapalha o trabalho

Mas por que não dizer o contrário?

O dia estando perdido

O salário será descontado

A menos que eu consiga

Descolar um atestado

Mandei meu filho

Ir ao bar do Seu Zé

Comprar pão e leite fiado

Apesar da miséria que ganho

No fim do mês

O acerto é sagrado

Nem tinha reparado

Como o moleque cresceu

Daqui a pouco

'Tá até maior que eu 
Queria ter mais tempo

Para cuidar que ele

Ande sempre no trilho

Mas se dou duro

O dia inteiro

É para que o filho

Do meu patrão

Não seja também

O patrão do meu filho

Meu barraco é o mais alto

$\mathrm{O}$ mais longe do asfalto

O mais perto do céu

Isso não é nenhum sacrilégio

Aliás é até um privilégio:

-Daqui de cima dá pra ver tudo:

O sino da igreja

O quintal da Dona Eurica

Mãe do Zeca Cabeçudo

Que lava roupa pra gente rica

E não é pouca

E não reclama, apesar da canseira

E enquanto esfrega

Vai cantando

Aqueles cantos de lavadeira

Lá embaixo, ao pé da seringueira

Tem um banco de madeira

Onde a velha-guarda se reúne

Pr'aquela conversa corriqueira

E um bom jogo de dominó ou carteado

Todo mundo aposentado

Gente cheia de sabedoria

Que aprendeu que a vida

Não é feita de correria

E que toda vez que amanhece

Acontece um novo dia

-Olha só quem vai ali!

Se não é a Maria

Mulher do Joaquim!

Que tinha um cachorro que corria

Atrás de mim

Quando eu pulava o muro

Pra roubar suas goiabas: 
-Ah, moleque sem vergonha!

Se te pego, vai levar umas palmadas

Perdi a hora

E pude perceber, por um instante

O que se passava bem diante do meu nariz

Que pra ser feliz

Eu preciso de tão pouco:

Dessas ruas sem asfalto

Dessas casas sem reboco

Perdi a hora e pude notar

Que o que a vida nos dá é de graça

Que nada em troca ela há de querer

Por isso, trabalhem

Trabalhem sim

Mas não deixem de viver (Serginho Poeta, 2007, p. 67-68).

A partir do recurso da desaceleração - produto da passagem da rotina do trabalho para o tempo de ócio (ou da economia da produção para a da despesa) -, o eu lírico do poema de Serginho Poeta instala-se em um presente do "estar aí", que registra rotinas, sons, movimentos e paisagens que reafirmam o "ser periférico" e criam uma cadeia sintagmática afetiva que redefine o termo "periferia", já não partindo da ideia de carência, mas, pelo contrário, de riqueza cultural.

É comum nos textos declamados pelos moradores nos saraus que se fale sobre a realidade sem focar a ação, isto é, sem espetacularizar a pobreza, mas concentrando-se em experiências do dia a dia e nos detalhes ínfimos que conformam a vida nas regiões pobres da cidade, como se pode perceber em "Faltei ao serviço". Uma vez que alguém que não mora nesses lugares não pode sequer imaginar esses aspectos mínimos, a voz periférica vê-se legitimada: não é qualquer um que possui esse saber, diz essa forma de narrar. Como afirma Regina Dalcastagnè: "Não se trata apenas da possibilidade de falar, mas da possibilidade de 'falar com autoridade', isto é, o reconhecimento social de que o discurso tem valor e, portanto, merece ser ouvido" (Dalcastagnè, 2012, p. 43). E não são as cenas de violência, mas os detalhes enquanto estética, que autorizam essas vozes. O mecanismo de ressignificação do "ser periférico" por meio da poesia não é, portanto, exclusivamente temático; há também um estilo comum que o articula: o esforço pelo detalhe, a periferia narrada com lupa.

A maioria dos saraus de poesia está na Zona Sul da cidade de São Paulo, onde o hip-hop tem uma presença marcante (recorde-se que é dessa 
região que procedem os Racionais $M C^{\prime}$ s, Facção Central, Z'africa Brasil, Sabotage, Criolo etc.). É comum, nesse sentido, escutar a declamação de textos construídos em sintonia com as letras de rap (e até declamados com as rimas e os gestos corporais dos manos e minas). Assim, a conformação de um "ser periférico" resignificado também se articula nas poesias que circulam nos saraus por meio da conformação de um sujeito lírico como representante de um coletivo que tem o mesmo inimigo. Isso está presente, por exemplo, em um fragmento de "Nosso manifesto", do Coletivo Cultural Poesia na Brasa, chamado "A elite treme":

A elite encontra-se nos grandes centros comerciais, rodeada pelas periferias que ela própria inventou / a periferia se arma e apavora a elite central / Nas guerras das armas, os ricos reprimem os favelados com a força do Estado através da polícia / Mas agora é diferente, a periferia se arma de outra forma / Agora o armamento é o conhecimento, a munição é o livro e os disparos vêm das letras [...] (Coletivo Cultural Poesia na Brasa, 2009, p. 31-32).

"A elite treme" dá conta de uma operação de ressignificação comum nas poesias dos poetas periféricos: o trânsito do sistema semântico habitualmente associado ao crime para o universo da literatura e a denúncia da violência por parte dos agentes que geralmente se apresentam como vítimas. Trata-se de uma operação dupla: a desterritorialização das operações criminosas e a ressignificação das identidades criminalizadas.

É importante ressaltar que a diferenciação e a valorização do "ser periférico" praticadas nos saraus não se realizam apenas nos textos mas também no corpo dos declamadores, que, acompanha e enfatiza esses propósitos. Ser poeta de sarau complementa-se com o corpo. Augusto Poeta, por exemplo, define-se não apenas por sua assinatura, mas, igualmente, pela forma de ler sua poesia escrita à mão em um papel enrugado (às vezes no verso de um folheto) que tira do bolso segundos antes, com o microfone na mão e um vai-e-vem corporal que acompanha as rimas de seu "cordel urbano". Já Luan Luando sempre declama, nunca usa o microfone, e aqueles que o escutam esperam as partes dos poemas em que o poeta pede que o acompanhem, agitando-as com o braço esquerdo, pois o outro padece de uma paralisia. Dona Edite, uma idosa cega que nunca falta ao sarau da Cooperifa, sempre é acompanhada até o microfone para declamar alguma poesia mexendo os braços esticados diante de seu corpo, de cima para baixo, como um pastor. Por sua vez, Kênia costuma começar a declamar sua versão do "Navio negreiro" de viva voz desde o lugar em que está sentado, aproximando-se do microfone com o movimento dos versos rapeados que termina de dizê-los amplificados pelo alto-falante. As formas de falar e de rimar, de aproximar-se do microfone, de ficar em pé, os movimentos das mãos e 
dos próprios corpos - que, muitas vezes, evidenciam cicatrizes, doenças e cansaço, ou músculos -, a presença e o caráter são afirmações do "ser periférico" que, por meio da repetição, instala esquemas motrizes que naquele ambiente tornam-se reconhecíveis e valorizáveis.

A periferia relatada e corporificada passa a conformar um bem complexo e não mais um estigma paralisante. Nas palavras de Pierre Bourdieu, pode-se dizer que se transforma em um capital simbólico:

El capital simbólico es cualquier propiedad (cualquier tipo de capital, físico, económico, cultural) cuando es percibido por agentes sociales cuyas categorías de percepción son de naturaleza tal que les permiten conocerla (distinguirla) y reconocerla, conferirle algún valor (Bourdieu, 1997, p. 108).

Nesse sentido, "a periferia", durante os saraus, é compreendida como uma propriedade com características particulares e complexas, que lhe conferem um valor específico e que tem a qualidade, como todo bem, de poder ser exibida, intercambiada, estilizada e reconhecida. A "periferia" converte-se, assim, em um capital dinâmico, já não é mais um conjunto determinado de bens.

O espaço privilegiado para a circulação desse capital simbólico é o sarau e não são apenas os declamadores que exibem esse bem diante do microfone mas também os próprios frequentadores. Do lado de fora, quando as pessoas encontram-se ou despedem-se, é comum escutar, entre os homens principalmente, "É nóis", "firmeza", "tamo na luta", "E aí parceiro", frases acompanhadas por olhares diretos, um aperto de mão e, em seguida, uma aproximação lateral dos corpos, como se estivessem batendo os ombros contrários. Nas palavras de Goffman, essas cerimônias poderiam ser compreendidas como um ritual:

Los pequeños saludos, cumplidos y disculpas que salpican las relaciones sociales se pueden denominar "rituales de status" o "rituales interpersonales". Empleo el término "ritual" porque esta actividad, por informal y secular que sea, representa una forma en que el individuo debe proteger y designar las consecuencias simbólicas de sus actos, mientras se encuentra en presencia inmediata de un objeto que tiene un valor especial para él (Goffman, 1970, p. 56).

Esses cumprimentos nos saraus têm consequências simbólicas que não se concretizam quando são exibidos em uma esquina qualquer. As formas de cumprimentar-se e de despedir-se que constantemente são vistas na porta dos bares no dia do sarau têm o valor particular de transmitir a ideia de "tamo junto". O destinatário que recebe o cumprimento funcionaria como uma extensão do capital "periferia" confirmando o laço chamado 
"Movimento": "Dentro do sarau é que você faz a poesia, fora do sarau você articula o movimento, entendeu? Você está alí pensando o movimento", afirma (em entrevista à autora) Luan Luando, um poeta periférico que frequenta esses espaços.

Pois bem, como todo evento no qual a voz ocupa um lugar central, é importante considerar que os receptores não são sujeitos vazios durante a declamação. Ao mesmo tempo que participam da afirmação do "capital periferia" a partir da sociabilidade do lado de fora do sarau, participam das declamações a partir do silêncio e do aplauso. Todo sarau da periferia tem essas duas fórmulas como divisa para todos os que estão presentes no bar. Ao apresentar o poeta e ao final da declamação, os organizadores instigam o aplauso com a frase "uma salva de palmas!", e, se a resposta não é suficientemente efusiva, estimulam os frequentadores com um "fraco!", ou com um "vamos fazer barulho!". Além disso, muitos dos saraus sustentam explicitamente o lema do silêncio escrito nos cartazes: "O silêncio é uma prece", insiste a Cooperifa, por exemplo, todas as quartas-feiras no bairro da Chácara Santana. Todos os saraus da periferia mantêm essa ordem ritualizada - apresentação, silêncio e aplauso - especificando em cada caso a noção de "respeito" como motor. Nas palavras de Sérgio Vaz (em entrevista à autora):

Então a gente trata as pessoas comuns, assim, né? Por isso que o aplauso é igual, se chama da mesma forma, a gente procura sempre não aplaudir mais um do que o outro, não existe o melhor da noite. O seu Lorival, que é uma pessoa simples, é tão aplaudido quanto o Rodrigo Ciríaco, que é um professor, e assim que a gente vai.

O aplauso indistinto depois de cada poesia chama firmemente a atenção de quem se aproxima dos saraus pela primeira vez, já que entre os poemas há, muitas vezes, grandes diferenças que fazem com que uns sejam mais apreciados que outros. Torna-se necessário entender, de qualquer modo, que esses aplausos não estão motivados pela noção de "gosto". A ideia de "gosto" letrado, individualizado e fortemente associado à sensibilidade pessoal não é a que está por trás desses aplausos. O aplauso aqui não está motivado pela ideia de um observador/receptor individual, que mobiliza seu juízo estético. Pensar essa prática desde esse enfoque letradocêntrico levaria a afirmar uma "ingenuidade do olhar" periférico em relação às formas estéticas. Porém, o que o aplauso expressa, isso sim, é uma ação coletiva que reforça a construção de uma identidade periférica ressignificada a partir do orgulho, despojada da comparação humilhante com respeito aos sujeitos de tradição letrada. Então, o aplauso, do mesmo modo que o silêncio, associa-se aqui a um ato não individual, mas relacional. 
Nesse sentido, pode-se entender a reiterada afirmação na Cooperifa, "o silêncio é uma prece", visto que, de acordo com Marcel Mauss, a plegária não é simplesmente um fenômeno individual, uma "efusão da alma", ou um "grito de um sentimento", mas, sobretudo, consiste em um fenômeno coletivo (Mauss, 1979, p. 117) que, como tal, cumpre uma função na economia moral das relações sociais. Expresso de outro modo, o silêncio e o aplauso funcionam como uma linguagem corporal que age na dinâmica coletiva do sarau imprimindo uma ideia de "respeito" fortemente relacionada ao reconhecimento das capacidades dos frequentadores. É nesse sentido que o organizador Sérgio Vaz reflete (em entrevista à autora): "Este é um projeto que visa levar autoestima à comunidade".

O silêncio e o aplauso são atitudes coletivas, e a ausência de ambos é o que denota uma apreciação individual. De fato, Alisson, poeta e assíduo frequentador dos saraus da periferia, afirma (em entrevista à autora) que o que mais o entusiasma como poeta é quando as pessoas reagem de modo não esperado frente a uma declamação.

Eu gosto de falar assim: eu preferia um minuto de silêncio do que um minuto de aplauso. Por isso, eu apresento umas poesias para causar silêncio, pra fazer que aquilo ecoe. A fala é o feminino do falo e os dois têm um ato de penetração, então quando eu vou declamar um poema, eu quero penetrar no ouvido daquelas pessoas, me imaginar nelas, quero chegar nelas. E o silêncio é quando eu sinto que eu cheguei nas pessoas, quando eu percebo que fica alguns segundos de silêncio, que você vê o silêncio, que você vê o silêncio ganhando corpo. Aí depois se rola aplauso ou não, pra mim não faz muita diferença. Mas quando rola o silêncio aí você fala assim: “Porra!, cheguei!" Essa poesia é comunicável.

Existiriam, assim, duas formas de silêncio: o silêncio durante a declamação, motivado pelo respeito coletivo, e o possível silêncio posterior, motivado pelo juízo estético individual. Tanto em um caso como em outro, o silêncio não remete nunca à ideia de "erro", mas sim possui uma função comunicativa poderosa, tanto individual quanto coletiva. É desse modo que o silêncio adquire um sentido pleno nos saraus. A distinção dos modos e funções do silêncio e do aplauso torna-se central para observar que nos saraus da periferia funciona também uma ideia de "gosto", apesar de expressar-se com mecanismos corporais diferentes aos dos espaços da tradição letrada.

Para poder entender o universo dos saraus da periferia, é fundamental assinalar que as declamações não são um discurso verbal autossuficiente em si mesmo, mas que se trata, isso sim, de um evento social, que exige uma reflexão sobre outras variáveis além da letra. A declamação é um evento e, como tal, muitos de seus significados encontram-se fora do texto e ra- 
dicalmente condicionados pela realidade social que lhe deu sustentação, marcada pela pobreza econômica e a exclusão política. Daí muitos desses discursos terminarem configurando-se como instâncias interpelativas da realidade social, assim como a mesma realidade social impõe suas marcas nas declamações e nos próprios saraus. Levando em conta essa característica, entende-se o porquê de se ouvirem nos saraus não declamações de poemas mas de o microfone também funcionar como espaço de denúncia, de desafogo, de discussão, de debate, dependendo do momento político ${ }^{4}$ do bairro. Assim, o estudo dos saraus exige, além de uma referência aos poemas, poetas e frequentadores, uma análise da "geografia" do sarau, isto é, do bairro em que está localizado cada sarau e o bar em que se desenvolve.

Neste ponto é necessário destacar que os saraus da periferia de São Paulo não são todos iguais. Os saraus diferenciam-se involuntariamente entre si pelos bairros e pelos espaços físicos em que estão montados. O Sarau da Cooperifa, por exemplo, é realizado em um bar que está em uma esquina elevada, rodeado de casas. $\mathrm{O}$ silêncio do bairro residencial, somado à particular localização do bar, faz com que tudo o que aconteça ali dentro ecoe ao redor. Essa circunstância influi tanto nesse sarau que, à diferença dos outros, o obriga a ter um horário de fechamento estrito. Sérgio Vaz (em entrevista à autora) diz a respeito: "Tem um problema aqui que é a comunidade, nós temos um acordo com eles que é acabar às 11 horas, então se a gente vai fazer alguma coisa para enaltecer a comunidade, você não pode começar agredindo a comunidade". Além da influência do bairro no sarau, a arquitetura do interior dos bares é também um fator que particulariza cada sarau. O Bar do Santista, onde se realiza o Sarau Elo da Corrente todas as quintas-feiras, no bairro de Pirituba, por exemplo, diferentemente de outros bares, é muito pequeno, parece quase um corredor, não há um salão principal. Há um balcão e uma biblioteca ao lado (todos os bares em que há saraus possuem uma biblioteca), ${ }^{5}$ e um espaço livre pequeno onde as mesas entram apertadas. $\mathrm{O}$ microfone fica ao fundo, em frente ao banheiro, e os frequentadores ficam parados junto do balcão, na porta e em parte da calçada. Como conta (em entrevista à autora) Michel, um dos organizadores:

A gente acaba criando uma peculiaridade nossa, acho que cada sarau é um sarau e independe de estar de um movimento só, mas a Cooperifa não é como o Binho, o Binho não é como Brasilândia, Bra-

\footnotetext{
${ }^{4}$ Durante as eleições presidenciais de 2010 era comum ouvir Sérgio Vaz gritar, entre poeta e poeta, "A Cooperifa é Dilma".

5 Neste artigo não desenvolvo o papel da biblioteca nos saraus da periferia. Para uma análise mais detalhada a respeito, conferir o capítulo 3 de “;Cuidado con los poetas! Una etnografia del mundo de la literatura marginal de la Ciudad de San Pablo” (Tennina, 2011).
} 
silândia não é como o Elo da Corrente. Podem estar, muitas vezes, até as mesmas pessoas, isso é natural, porque tem o gosto da literatura, então atravesso a cidade mesmo para ir poder falar minha poesia [...] E o Bar do Santista é pequeno, então propõe que tenha menos pessoas? Tem! Menos pessoas, com certeza. Mas, até nesse sentido acaba sendo mais íntimo [...] Até surgiu um apelido recentemente que falaram assim que lá é um "alçapão". É um "alçapão da poesia". Existem pessoas que chegam ali, rappers famosos, que chegam ali e tremem na hora de recitar lá. Porque as pessoas estão "aqui" na sua cara, quando você está falando.

O particular espaço reduzido do Bar do Santista faz com que seja muito chamativa a divisão entre o que está dentro e o que está fora do sarau, e, além disso, faz com que a circulação da rua (barulho de carros, cachorros vira-latas, bêbados) afete ou interfira mais nas declamações que em outros saraus maiores e menos expostos (como Cooperifa ou o Sarau da Brasa).

O próprio ritual de cada sarau também os diferencia entre si. Apesar de o Sarau da Cooperifa ter funcionado como um modelo inspirador, principalmente a partir do estabelecimento rigoroso de fórmulas comuns a todos os saraus - tais como o silêncio, o aplauso, o foco na literatura e não na música, o tempo das declamações -, não se pode falar da Cooperifa como uma sinédoque de todos os saraus da periferia. Como assinala (em entrevista à autora) um dos organizadores do Sarau Poesia na Brasa: A gente tomou a Cooperifa, inicialmente, como uma referência, mas ao mesmo tempo tentando se distanciar do modelo que eles fazem. A gente trabalha junto com a Cooperifa, a gente gosta da Cooperifa, mas eu acho que a riqueza deste movimento que está tendo de saraus, é que cada um faz do seu jeito, embora todo mundo está trabalhando juntos, mas cada um faz do seu jeito. Então teve esse lance da Cooperifa servir como uma referência pra gente, mas, isso logo inicialmente... Hoje em dia, já... Embora a gente trabalhe junto, não tem nada a ver o Sarau da Brasa com o Sarau da Cooperifa.

Há, ademais, variedades temáticas que os organizadores dos saraus lhe imprimem. O Sarau da Brasa, por exemplo, que se realiza no meio dos sábados no bairro de Brazilândia, Zona Norte de São Paulo, chama a atenção, se o comparamos com os saraus da Zona Sul, porque tem início e termina com tambores e cantos que, primeiro, chamam e, depois, despedem os poetas do sarau. O Sarau da Brasa pretende ter a particularidade temática da negritude, isto é, que paralelamente ao trabalho de ressignificação da periferia, que continua sendo o propósito principal e comum a todo sarau, há um acento na ressignificação das práticas afro-brasileiras. Comenta Vagner (em entrevista à autora) a respeito: 
Aqui no Sarau da Brasa, quando a gente propõe, no começo e no final, bater tambores. Essa prática de tocar tambores tem a oralidade como carro-chefe, também é um jeito que a gente encontrou de resgatar a ancestralidade negra, mesmo, né? Por exemplo, eu acho que vários saraus que fazem questão da oralidade não pensa muito nesta questão da ancestralidade negra, aqui a gente tenta pontuar sempre. A gente está fazendo isso porque é pra ser um resgate de ancestralidade. Por isso que a gente bate tambor.

Essas particularidades temáticas muitas vezes são marcas inscritas pelos organizadores dos saraus, que lhes dão esse aspecto, além de estabelecer um modo particular de apresentar os poetas e de iniciar e terminar o sarau. Como diz Luan Luando (em entrevista à autora), poeta citado anteriormente: "cada tribo rege de acordo com o seu cacique [...] O Binho, o Vaz, o Fernando. ${ }^{6}$ Cada um tem o seu modo de fazer [...] Eu levanto a bandeira do Binho. Eu estou na maioria dos projetos do Sarau Binho... Eu sou do Binho, porra! Eu sou do Binho!". O Sarau do Binho tem a particularidade da distensão das fórmulas: ali não há a exigência com respeito ao tempo das declamações nem a que sejam apenas poesia. Como diz Allan da Rosa (frequentador do Sarau do Binho, escritor com vários livros publicados e editor das Edições Toró):

Este sarau, o mais antigo e dos mais cooperativos de São Paulo, mesmo levando o nome de seu idealizador, tem a agenda guiada pela demanda da comunidade. Quase toda semana chega alguém, algum coletivo, com um livro pra lançar, uma urgência pra debater, uma animação pra projetar. O Sarau do Binho tem a pauta levada pela beirada da Zona Sul e não é uma marca que visa crescer o ibope do Robinson ${ }^{8}$. É um encontro com o encanto, com estética, com a política (Da Rosa, 2012, s/n).

O sarau do Binho e todos os seus projetos, além disso, têm a particularidade de preocupar-se com latinoamericanizar a temática periférica. Ali podem ser ouvidas declamações em espanhol, são lidos autores como Mario Benedetti, Eduardo Galeano ou Antonio Machado, e uma das poesias do Binho mais ouvidas é precisamente "Ir ir e ir", que diz o seguinte:

\footnotetext{
${ }^{6}$ Fernando é o organizador do Sarau da Vila Fundão, que tem lugar todas as quintas-feiras no bairro do Capão Redondo.

7 O esclarecimento do "mais antigo" pode ser entendido se se considera as Noites da Vela como um sarau. Existe uma disputa com respeito à origem entre o Sarau da Cooperifa e o do Binho, levando-se em conta esse antecedente.

${ }^{8}$ O nome de batismo de Binho é Robinson.
} 
Quiero ver donde esta / América se desmorena / y se construye / donde se dice negra / donde se desmestiza / y se desmistifica / donde se andina / y se desanda / Quiero ver / donde el samba es más Gardel / donde el tango es Noel / donde el habla es el silencio de las pampas / [...] donde Neruda es Drummond / donde el guaraní es oficial / donde el Morumbi es la Bombonera / donde el Chile es Allende / donde ningún salvador es Pinochet/ Quiero ver quiero ver / donde el Paraguay venció / donde Alfonsina se entregó / donde el Brasil se Argentina más / donde el Uruguay es más Galeano / y donde yo soy más o menos brasileño / Quiero ver quiero ver (Binho, 2007, p. 31-33).

O poema foi publicado no livro lançado em 2007 pela Edições Toró. A obra é bilíngue e seu título procurou palavras comuns ao português e ao espanhol, Donde miras.

Pois bem, a particularidade temática de cada sarau não tem apenas a ver com uma motivação pessoal, mas também interferem preocupações vinculadas à gestão. Todos os saraus da periferia participam da política dos editais lançados por diferentes órgãos institucionais, e a originalidade e a pertinência dos projetos são aspectos fundamentais para receber o dinheiro. Nesse sentido, cada sarau se vê obrigado a pensar as diferenças entre um e outro para além do vínculo que os une como movimento. Diz a respeito (em entrevista à autora) Michel Yakini, um dos organizadores do Sarau Elo da Corrente, fazendo referência à semelhança que costuma encontrar com o Sarau da Brasa.

Mas a gente sabe que também é porque as pessoas visualizam que é unidade, né? Só que a gente toma cuidado, na hora não diz... Como deu esse problema, por exemplo, dum cachê, mas dá problema pra ele, na hora de aprovar um projeto, né? Já pensou, eu mando um projeto pra Prefeitura e eles mandam outro, daí o cara fala: "Pô! Elo e Brasa? Ah! Não. Mas isso é uma coisa só!" Então só vai aprovar um? Mas a gente atende Pirituba, eles atendem Brasilândia! Então, tem que tomar bastante cuidado pra isso não ficar misturado porque senão atrapalha nessas negociações com o Estado.

Torna-se necessário neste momento fazer referência à particular relação dos saraus com o Estado. Precisamente no início do movimento dos saraus deu-se uma mudança fundamental na política cultural desenvolvida pelo governo brasileiro. Com os primeiros passos do governo Lula, e a designação de Gilberto Gil como Ministro da Cultura, começou uma época de diálogo e reconhecimento para os movimentos culturais periféricos. A criação de programas orientados para o fomento do trabalho comunitário, como o Programa Cultura Viva, cuja principal ação é o re- 
conhecimento dos espaços e grupos culturais como Pontos de Cultura, contribuíram de forma substancial para a visibilidade e legitimidade desses espaços comunitários. Esse reconhecimento como espaço cultural por parte do governo é, em muitos casos, ainda mais importante que a transferência de recursos para o desenvolvimento dos projetos, uma vez que as manifestações culturais periféricas têm sido sistematicamente excluídas e discriminadas pelo mercado e pelos círculos consagrados.

Nessa conjuntura, o movimento dos saraus, ao ser alcançado por essas políticas, desenvolveu uma intensa relação com o Estado: alguns, associados com outros coletivos, são nomeados Pontos de Cultura, como o Sarau do Binho (associado à Agência Solano Trindade) ou o Sarau Palmarino (que forma parte do Circuito Palmarino). Essa relação, sem ser o eixo determinante para seu crescimento, foi de suma importância para sua consolidação ao somar participação, não apenas em programas específicos mas também em mesas para elaboração e gestão de políticas e programas para as periferias.

É importante assinalar, de qualquer modo, que o empoderamento da cultura periférica supera o apoio estatal, algo que ficou evidente com o fechamento do Bar do Binho -, e, como consequência, do sarau que se realizava ali todas as segundas-feiras -, pela Prefeitura de São Paulo, em maio de 2012, devido à ausência de uma licença negada durante oito anos. O fechamento do bar, que, como mencionamos anteriormente, foi reconhecido em 2010 como Ponto de Cultura - sem dúvida uma das contradições desse tipo de política -, gerou uma reação e uma manifestação de repúdio à medida da Prefeitura, além de uma repercussão no campo da cultura impensável no momento de sua gestação, em 2004. Houve mobilizações, saraus do Binho em diversos espaços, relatos em programas de televisão, notas em jornais nacionais e internacionais, expressões de apoio de personalidades públicas e uma significativa ajuda econômica procedente de diferentes fontes para arrecadar fundos para as multas do local. Foi graças à repercussão dessas manifestações que o Sarau do Binho pôde continuar:

O sarau continua sim, a gente não vai desistir. Agora será um sarau itinerante, na medida do possível, conforme a gente conseguir fazer e se locomover. A gente vai fortalecer outros espaços culturais, outros parceiros que apoiam a causa e que estão junto com a gente. Então nós vamos circular um pouco com o sarau (Neto, 2012, s/n).

De qualquer modo, essa continuidade do sarau foi possível a partir de uma mudança fundamental vinculada a um de seus elementos definidores, a territorialidade. Assinala Binho, em entrevista concedida ao jornal Brasil de fato no dia 13 de junho de 2012: 
A maior perda é não ter mais um espaço em que você construía a memória. Embora a gente tenha muita coisa gravada e registrada, acabamos perdendo a referência do espaço físico também. Fora a relação que a gente tem de pertencimento. Ali era um local em que as pessoas recitavam seus poemas e exercitavam seus pensamentos. Esse era o nosso "estar no mundo", e acabamos perdendo isso também (Neto, 2012, s/n).

A perda do bar, como se pode perceber, não significa que se pense o fim do sarau: o sarau continua sendo possível para além de sua localização. Essa decisão deixa manifesto que, ao longo do processo do movimento de saraus da periferia, o capital simbólico que os identificava foi tornando-se cada vez mais sólido e reconhecível, o que, por sua vez, possibilitou pouco a pouco o desprendimento de seu território e uma maior circulação. Essa mudança já havia sido iniciada com o Sarau Suburbano Convicto, sob a responsabilidade de Alessandro Buzo, inaugurado em 2010 em um bairro não periférico, mas do centro da cidade (Bixiga), e não em um bar, mas na livraria desse escritor (Suburbano Convicto). Isso ficou claro também com o Sarau de Ademar, inaugurado em 2009. Devido a problemas que tiveram durante o ano de 2010 com os donos dos diversos bares em que o evento tentou instalar-se, seus organizadores acabaram fazendo saraus em um campinho de futebol do bairro.

Pode-se afirmar que se está diante de uma nova etapa do movimento de saraus da periferia. O reconhecimento territorial que os definiu, a partir dos bares e de sua localização, adquire, em alguns deles, outro tipo de funcionamento que supera a territorialidade. Coloca-se, assim, uma questão: qual rumo terá o movimento dos saraus da periferia frente a esse tipo de deslocamentos? Não é possível dar uma resposta a essa pergunta. Pretender dar uma resposta implicaria negar a potência do movimento de saraus da periferia, porque, nesse caso, estariam respondendo a uma fórmula. Os saraus da periferia não consistem em um esquema predeterminado, mas em um conjunto dinâmico de elementos em formação e reformulação constante, razão pela qual uma análise desses eventos não pode centrar-se na mecânica do modelo, mas na dialética das estratégias (Bourdieu, 2007, p. 160). E é justamente esse dinamismo que lhes dá vitalidade.

\section{Referências}

BINHO (2007). Ir, ir e ir. In: Donde Miras. São Paulo: Toró.

BOURDIEU, Pierre (1997). Razones prácticas. Barcelona: Anagrama. (2007). El sentido práctico. Buenos Aires: Siglo XXI.

COLETIVO CULTURAL POESIA NA BRASA (2009). A elite treme. In: Coletivo 8542. São Paulo: Coletivo Poesia na Brasa. 
DALCASTAGNÈ, Regina (2012). O lugar da fala. In: Literatura brasileira contemporânea: Um território contestado. Vinhedo: Horizonte; Rio de Janeiro: EdUERJ. DA ROSA, Allan (2012). Lesmas comandadas por raposas (e o fechamento do bar do Binho). Bola e arte. Disponível em: <http://bolaearte.wordpress. com/2012/06/01/lesmas-comandadas-por-raposas-e-o-fechamento-do-sarau-do-binho-por-allan-da-rosa>. Acesso em: 1o dez. 2012.

DURKHEIM, Émile (1965). Introducción. In: Las formas elementales de la vida religiosa. Buenos Aires: Schapire.

GOFFMAN, Erving (1970). El ritual de interacción. Buenos Aires: Tiempo Contemporaneo.

PINHO, Wanderley (2004). Salões e damas do Segundo Reinado. São Paulo: Gumercindo Rocha Dorea.

NETO, José Francisco (2012). Kassab fecha o cerco sob saraus da periferia. Brasil de fato. Disponível em: <http://www.brasildefato.com.br/node/9808>. Acesso em: 1ㅇ dez. 2012.

MAUSS, Marcel (1979). A prece (1909). In: Antropologia. São Paulo: Ática.

SERGINHO POETA (2007). Faltei ao serviço. In: Donde miras. São Paulo: Toró.

SILVA, Simone (2004). As rodas literárias nas décadas de 1920-30: troca e reciprocidade no mundo do livro. Dissertação (Mestrado em Antropologia Social) -Museu Nacional, Universidade Federal do Rio de Janeiro, Rio de Janeiro.

SORÁ, Gustavo (2010). Brasilianas: José Olympio e a gênese do mercado editorial brasileiro. São Paulo: EDUSP.

TENNINA, Lucía (2011). ¡Cuidado con los poetas! Una etnografía sobre el mundo de la literatura marginal de la Ciudad de São Paulo. Dissertação (Mestrado em Antropologia Social) - Instituto de Altos Estudios Sociales, Universidad Nacional de San Martín, Buenos Aires.

Recebido em dezembro de 2012.

Aprovado em abril de 2013.

\section{resumo/abstract}

\section{Saraus das periferias de São Paulo: poesia entre tragos, silêncios e aplausos}

\section{Lucía Tennina}

Este artigo apresenta um panorama do movimento dos saraus da periferia a partir da hipótese de que os saraus da periferia articulam uma nova concepção do espaço "periferia". O trabalho parte da análise das fórmulas rituais que nele se desenvolvem e as variadas dimensões de construção de identidades periféricas pensadas 
desde a ideia de cultura. A análise atinge também os estilos dos poemas que costuma se declamar nesses espaços. $\mathrm{O}$ artigo insiste em marcar as diferenças entre os saraus da periferia, principalmente diferenças geográficas e temáticas, fazendo referência também à gestão das políticas culturais que dialoga com esse movimento de saraus da periferia. Finalmente, reflete-se aqui em relação com o processo atual dos saraus da periferia, a partir da desterritorialização de muitos deles.

Palavras-chave: saraus da periferia; periferia; São Paulo; literatura periférica.

\section{Saraus from São Paulo's periphery: poetry between drinks, silences and palms.}

\section{Lucía Tennina}

This article presents the scene of sarau's movements from São Paulo's periphery since de hypothesis that the saraus from de periphery articulates a new conception of the space "periphery". This work starts with the analyze of the ritual's forms that are developed on those places and from the varied dimensions of construction of periphery's identities thought from de idea of culture. The analyze considers also the style of the poems that are frequently declaimed on those spaces. The article insists on pointed the differences between each sarau, especially geographic and subject's differences, referring also to the management of culture's politics which dialogues with this periphery sarau's movements. Finally, it is considered a reflection about the actual process of saraus from peripheries regions, considering the desterritorialization of many of them.

Keywords: saraus; periphery; São Paulo; periphery's literature. 